今日の話題

\title{
土壌構成元素の形態別定量評価の現状と展開 食料生産と環境保全の両立へ向けて
}

土㙵は，農業生産の基盤であるとともに，陸域生態系 の基盤でもあり，ヒトを含めた地球上の生物の生存を支 えている。 そのような観点から，土䗙に含まれる各種元 素の化学分析は実学的には従来大きく 2 つの目的で行な われてきた。 1 つは食料生産に関わる農業生産基盤とし ての土壌の肥沃度評価, 特に養分の供給および保持能力 の評価であり，もう 1 つは陸域生態系の基盤としての土 壌の健全性・安全性の評価である。ここで, 前者は植物 の必須元素を中心に分析が行なわれ, 特に多量必須元素 である窒素・リン・カリウムについてデータが蓄積され てきた ${ }^{(1,2)}$ のに対し，後者は生態系の健全性を損なう可 能性のある物質，たとえば重金属や希土類元素などが主 たる対象となってきた。

しかし，両者で対象とする元素がかなり異なること， またいずれも生物（特に植物）に対して可給度の高い (吸収されやすい) 画分に重点を置いて分析が行なわれ てきたことから，土䗙中の元素に対して網羅的な分析お よび解析が十分行なわれてきたとは言いがたいのが現状 である。一方で, 土袞を取り巻く環境は最近大きく変容 している，すなわち，農業生産の面からは，生産性（収 量）を高めることを第一目標にしていた時代から，収量 と品質の両立を目指すとともに環境への負荷の軽減屯試 みる時代へと移り変わりつつあり, 養分を過不足なく供 給することがより求められている ${ }^{(3)}$. また，環境保全の 面からは，従来重視されてきた，すぐに問題が生じるよ うな短期的な危険性を評価するだけでなく，長期的な安 全性を担保できるような評価を行なうことが求められる ようになってきている，その意味で，可給度の高い画分 だけでなく，可給度の低い画分をも含めた包括的評価が より重要視されつつある.

そのため, 各元素について可給度に応じた形態別定量 が進められている，たとえば窒素については，従来は易 分解性窒素（微生物によって容易に無機化=可給化され る画分）と全窒素の 2 項目しか主に評価されてこなかっ たが，無機態と有機態それぞれに対し可給態と非可給態 を評価する方法が提唱されている ${ }^{(4)}$ 。この手法を日本の 農耕地土壤に適用したところ, 全窒素（平均 $2,593 \mathrm{mg}$ $\mathrm{kg}^{-1}$ )を無機可給態 $37 \mathrm{mg} \mathrm{kg}{ }^{-1}$ ，有機可給態 $159 \mathrm{mg}$ $\mathrm{kg}^{-1}$, 無機非可給態 $124 \mathrm{mg} \mathrm{kg}^{-1}$, 有機非可給態 2,273 $\mathrm{mg} \mathrm{kg}^{-1}$ に分画することができ，可給態は全体の $7.6 \%$ を占めること，また可給態画分は水田と畑という土地利 用の影響を強く受けるのに対し，非可給態画分は母材に 大きく由来する土壌型の影響を強く受けることなどが明 らかとなった。言わば，非可給態画分は土袞の「氏」に， 可給態画分は「育ち」に強く規定されていると言える.

このことは, 日本の農耕地土袞の窒素環境を示すととも に，その管理についても示唆を与え，さらには日本を取 り巻く昨今の問題，たとえば家畜糞尿などの各種有機物 の農地還元を進めるにあたっても指針を与えるものと考 えられる。

さらに，ユーラシアのチェルノーゼムやタイの熱帯土 袞について同様の評価を行なっており，日本の土壤を世 界の土㙵の中で位置づけることも可能となりつつある。 すなわち，チェルノーゼムは日本と全窒素量はほぼ同じ であるにもかかわらず，低温乾燥という有機物の分解し にくい環境を反映し，特に有機可給態窒素の割合が高い こと（逆に日本が湿潤温暖であるにもかかわらずチェル ノーゼムと同程度の全窒素をもつのは, 反応性が高く有 機物を蓄積しやすい火山灰土㙵が多いことを反映してい る)，一方夕イ土壌は熱帯湿潤な有機物の分解しやすい 環境を反映し，全窒素が圧倒的に少なく可給態量もわず かであることなどが明らかとなった（図 1)。日本の農耕 地土壤の窒素環境を管理する際には，このような日本の 土壤の特徵を十分考慮する必要があろう。なお，土壤元 素の形態別評価を試みる同様の研究は, 他の元素, たと えば各種重金属 ${ }^{(5)}$ やセレン ${ }^{(6)} ， \exists ウ$ 素 $^{(7)}$ などでも行なわ れている.

また，形態とともに対象元素についても，すべての元 素を対象に各種形態を包括的に評価することが求められ ている，そこで，ICP-AES（誘導結合プラズマ発光分析 法）および ICP-MS（誘導結合プラズマ質量分析法）を 用いた多元素の形態別定量評価が日本の農耕地土壌につ いて進められている ${ }^{(8,9)}$.ここでは，宇宙の構成元素に ついて示された，原子番号が偶数の元素の存在量が隣接 する奇数の元素より高いというオッド・ハーキンスの法 則が土壌についても一般に成立していること，元素の化 


\section{今日の話題}

(A)

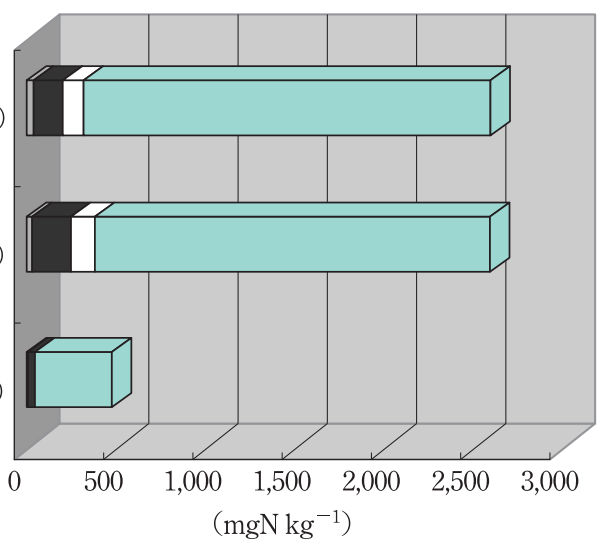

図 1 - 農耕地土壌の形態別窒素存在量

（A）日本，（B）ユーラシア（チェルノーゼム)，（C）タイ（熱 帯土壤). $\square$ 無機可給態, $\square$ 有機可給態, $\square$ 無機非可給態, $\square$ 有 機非可給態. (Sano et al. (2004) などから作成)

学的性質の類似性に対応して, その存在量や可給度につ いても相同性が存在すること, などが示されている。こ れらの知見は，土壌のなりたちを理解する上ではもちろ んのこと, 農業生産や環境保全との関わりの中で土壌を 管理していく上でも，貴重な基礎情報を提供している.

さらに言えば，環境が生命の存在様式に大きく影響を与 えることを考慮すれば，以前この闌で紹介された「メ夕 ロミクス (生体金属総合科学) 」(10) にもつながっていく ものと考えられる。

な扔，土畩は連続的な変異や不均一性をもつという意 味で, 生物個体や生命分子 (DNA・タンパク質) などと は異なる。したがって, 土壌の元素組成を評価する際に は, 対象の時間的また空間的なスケールについて十分に 考慮することが必要である。たとえば, 土壌と植物の関 わりで言えば, 空間的スケールでは根圈・根域・圃場・ 地域・地方・国・世界などが挙げられ, 一方で時間的ス ケールでは秒・分・時間・日・月・年・世紀・地質年代 などが挙げられる，管理という面から言えば，管理可能 なスケール，すなわち空間的には根域・圃場スケールで 時間的には日・月・年スケールあたりでの養分の動態を 解析すれば, 農業生産上より高い養分利用効率を実現し うる土壌管理手法を提示できることが示されている(11). また, 不均一な土㙵の取り扱いに関しては, 代表的デー 夕をどのように求めるかについても考慮が必要である.

その意味では, 土㙵試料のサンプリングについても，そ のデータの信頼性との関係で十分な検討が進みつつあ

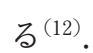

以上見てきたように，土壌の各元素の形態別評価を発 展させるとともにその評価を多様な元素について網羅的 に行なうことは, 基礎科学としても実学としてもさまざ まな可能性をもっている. 今後, 長期的展望に基づいて 日本の土壌の各種元素の形態別存在量に関する分析を進 めることにより, 我々が拠って立つ土壌環境について網 羅的データベースを構築し，日本の農業生産および環境 保全において有用な情報を発信できるようになること を，大いに期待するものである.

1) 小原 洋, 中井 信：日本土鎄肥料学雑誌, 74, 615 (2003).

2) 小原 洋, 中井 信：日本土袞肥料学雑誌, 75, 59 (2004).

3）小崎 隆, 渡辺和彦, 佐野修司, 矢内純太, 鳥山和伸, 松 本真悟, 阿江教治, 三島慎一郎：日本土䫓肥料学雑誌, 79, 113 (2008).

4) S. Sano, J. Yanai \& T. Kosaki : Soil Sci. Plant Nutr., 50, 501 (2004).

5）定本裕明, 飯村康二, 本名俊正，山本定博：日本土壌肥料 学雑誌, 65, 645 (1994).

6) Y. Kang, H. Yamada, K. Kyuma \& T. Hattori : Soil Sci. Plant Nutr., 39, 331 (1993).

7) H. Yamada, T. Kiriyama, Y. Onagawa, I. Hisamori, C. Miyazaki \& K. Yonebayashi : Soil Sci. Plant Nutr., 45, 563 (1999).

8) S. Yamasaki, A. Takeda, M. Nanzyo, I. Taniyama \& M. Nakai : Soil Sci. Plant Nutr., 47, 755 (2001).

9) A. Takeda, H. Tsukada, Y. Takaku, S. Hisamatsu, J. Inaba \& M. Nanzyo : Soil Sci. Plant Nutr., 52, 406 (2006).

10) 原口紘互：化学之生物, 46, 6 (2008).

11) 矢内純太：日本土壌肥料学雑誌，77, 505 (2006).

12）矢内純太, 松原倫子, 李 忠根, 森塚直樹, 真常仁志, 小 崎 隆：日本土壌肥料学雑誌，79, 61 (2008).

(矢内純太, 京都府立大学生命環境科学研究科) 